\title{
Accreditation and Certification as Key Factors of Quality in Higher Education in Engineering Schools, in Mexico
}

\author{
José Manuel Castorena Machuca ${ }^{1,}$, , María Lisseth Flores Cedillo², \\ Ma. de la Luz Morales Barbosa ${ }^{2}$, Hulda Zulema delÁngel López ${ }^{2}$, Patricia Castorena Briones ${ }^{3}$ \\ ${ }^{1}$ Department of Industrial Engineering, San Luis Potosi Institute of Technology, San Luis Potosi, Mexico \\ ${ }^{2}$ Department of Industrial Engineering, Higher San Luis Potosi Institute of Technology, San Luis Potosi, Mexico \\ ${ }^{3}$ Department of Human Resources, San Luis Potosi Institute of Technology, San Luis Potosi, Mexico
}

Email address:

jmkatcslp_01@yahoo.com (J. M. C. Machuca)

${ }^{*}$ Corresponding author

\section{To cite this article:}

José Manuel Castorena Machuca, María Lisseth Flores Cedillo, Ma. de la Luz Morales Barbosa, Hulda Zulema delÁngel López, Patricia Castorena Briones. Accreditation and Certification as Key Factors of Quality in Higher Education in Engineering Schools, in Mexico. Higher Education Research. Vol. 6, No. 1, 2021, pp. 11-19. doi: 10.11648/j.her.20210601.12

Received: December 4, 2020; Accepted: December 23, 2020; Published: January 15, 2021

\begin{abstract}
The topics of Evaluation, Certification and Accreditation of Educational Institutions, are very necessary to work in Higher Education in Industrial Engineering based on ISO 9001: 2015. The aim is to achieve the accreditation of the ITSLP educational program Areas of program support such as Planning and Maintenance to All Areas, Curriculum and Evaluation of Learning, Sport and Culture, School Control, Academic Engagement of Students themselves, Computer Center, Library, Human Resources, Basic Sciences, Linking with Public and Private Companies, Research and Technological Development, adequate and transparent management of resources, gender equity, mobility, sustainability, infrastructure and equipment, and communication with parents, and respect throughout the educational community, the preparation and academic development of teachers, the efficiency, relevance and impact of students as a social service, residence and even the impact of graduates in their field of work. On an ISO basis, with methodology of complying with the 10 CACEI categories, with development of compliance with them and with the result of Accreditation of the educational program. The results were successful, as the accreditation of the program was achieved, which makes it certified to offer clients, in this case higher education students, as well as other external clients such as employers and other education agents. And feedback was obtained from graduates and heads of departments that serve students with the leadership of managers and administrators.
\end{abstract}

Keywords: Evaluation, Accreditation, Certification, Equity, Relevance, Pertinence, Effectiveness, Efficiency

\section{Introduction}

This article is analyzed and interpreted at least a priori, first with regard to the future of evaluation: as a desire to improve the evaluation of the entire educational process and not only of teachers and students, but based on a benchmarking to see what strengths and weaknesses are in each educational institution, to make an objective diagnosis of how we are and based on that to know where we want to go as a better project that is measurable, rhetorical or achievable.

And second: not to remain only in a misleading advertising in schools but to have a system of indicators that allow setting goals and objectives to achieve them based on a comprehensive evaluation system that includes ways of studying, of evaluating the performance of teachers and the effectiveness of the school system with its resources, processes, teamwork with other educational agents and having a portfolio of evidence that we comply with what we say we do.

All this will bring the improvement of a collaborative work in schools that is reflected towards society.

Third: and regarding the quality of education through an Educational Management System [3], first, cover and have evidence with the specifications of the curriculum design that in addition to being pertinent and relevant makes us 
competitive with other institutions in such a way that they compare us And say this institution has this advantage and there I want to have my children studying.

This means that a national and international educational project must be complied with, where there will be governing bodies of the educational processes that certify and accredit that the quality standards that meet the expectations of society are met.

And that if you want to participate you need to invest resources and dedication, and that unfortunately companies that do not certify will be left behind.

And finally in third place: the urgency driven by globalization that in basic education schools it is connive that they socially demonstrate that they comply with a quality management program in higher education, because there is no other way than to actively participate in accreditation and certification programs of education programs and processes before prestigious national and international organizations such as CIEES or CACEI, ISO 9001: 2015 certifying companies

All this comes through UNESCO [13] where education is promoted in all countries to focus on the important areas of Quality in the educational process, comprehensive evaluation and quality certification and accreditation of its programs educational.

Hence, in each country improvement changes are promoted to participate in Loans and donations programs, and that institutions have to demonstrate that they are competitive at the national and international level through the certification agencies.

Where the evaluation of the educational process will show that there is an estimate of the satisfactory degree of both the process and the product.

The evaluation criteria must be met and based on physical and digital evidence of:

1) Institutional planning and development

2) Supporting services

3) Careers or educational programs

4) Teaching plant

5) The students

6) Graduates and the impact on society

7) Sustainability

All this provides the accrediting and certifying bodies (COPAES, ACEI, CIEES, ISO, etc., with a positive assessment that, on the one hand, will give advantages to the institution that certifies and accredits, first from an external recognition that carries it to a national international plane of excellence with which you can access scholarships for teachers and students and obtain other financial support.

As it can be concluded, to obtain an accreditation or a certification, it will be an effort of all the agents that intervene in the education of the school that participate in the effort of being an institution that offers a quality education [10].

State of the art.- UNESCO, 2014, recommends implementing the following 5 principles that agree on what educational quality is at the international level [9].
1. Equity: Needs of each person ensuring that everyone has differentiated opportunities to realize their right to education

2. Relevance: that it generates significant learning that fulfills the what and why of education as well as the learning of skills to participate in the areas and challenges imposed by a knowledge society and the individual life project in relation to others.

3. Relevance: Take into account the social contexts and characteristics of the students in congruence with the curriculum to be developed, in such a way that the educational contents are meaningful, consistent and avantgarde.

4. Efficacy: refers to the measure and proportion in which educational objectives are achieved and that is what is observed and valued as the impact of education.

5. Efficiency: It is the relationship between the expected educational purposes and the learning achieved, through the optimal use of the resources allocated for it.

The readers of this article will undoubtedly agree that these are major issues of educational evaluation, and that diagnostic evaluation in educational institutions of higher education in Mexico are already a reality and that on the one hand they provide an assurance of the quality of the educational process because they improve the evaluation of the performance of all the agents that intervene in education and the rendering of accounts of the directive and administrative authorities.

(Márquez Jiménez, 2004)Regarding the issue of Quality and Accreditation (ANUIES) [7] we learn that it is derived from a line that comes from UNESCO, and that focuses mainly on seeking a balance in all steps of the educational process:

1) Preparation and commitment of teachers

2) Willingness and commitment of students

3) Characteristics of the Educational Model

4) Validity, relevance and relevance of the curriculum

5) Nature of service and academic support

6) Infrastructure

7) And the effectiveness of management.

As for ISO 9001 certifying companies, they seek reliable compliance with physical and digital evidence of the educational process, as well as the product or service that is provided to meet the expectations of internal and external customers.

Regarding accrediting companies such as COPAE, CACEI, CIEES, etc., they are schemes in Latin America and with recognition in other countries, which validate the accreditation of the educational program to be evaluated. They do so based on an assessment of compliance with international standards and what they manage to accredit receives a recognition that endorses the effectiveness, efficiency, relevance, equity, and other factors to evaluate in educational institutions that leads them to a ranking of Accredited and Certified Schools of permanence classification as quality schools in higher education.

These ranking of National and International competitiveness in the reliability and quality of educational processes [4], take into account the preparation of full-time 
professors and their academic productivity when participating in academic bodies where they have to demonstrate that they comply with the Desirable Profile, which They do Research work, that have editorial work and that participate in a Number of Postgraduate Program, all activities that raise the academic performance of the Educational Institution.

\section{Methodology}

This work consisted of two well differentiated phases

Phase 1: Train in the ten CACEI categories for the accreditation of Industrial Engineering at the Technological Institute of San Luis Potosí

Phase 2: Get trained in ISO 9001: 2015

\subsection{Accreditation}

In Mexico, the company to accredit Engineering educational programs is CACEI, supervised by COPAES (CACEI, Itson, 2018) [5].

The Council for the Accreditation of Engineering Education, Civil Association, was formally constituted on July 6, 1994, as a civil association whose highest governing body is its Assembly of Associates, in which the schools participate, associations representing higher education or professional institutions; the federal government, represented by the General Directorate of Professions; as well as the productive sector, through the corresponding chambers [11].

The CACEI is the first accrediting body that is established in our country and performs a function of great importance, since it contributes to the improvement of the quality of engineering education and provides timely, pertinent and objective information, which is of great value. for educational institutions, students, teachers, graduates, employers and parents (https://www.asee.org/, 2020).

The accreditation process that is developed is voluntary, takes into account the internationally accepted criteria by similar organizations and those established by the Council for the Accreditation of Higher Education (COPAES). It is carried out with the active participation of peer evaluators from the academic and productive sectors.

Decisions on the quality of the educational programs evaluated are collegiate and, with the information provided to the institutions, it is sought to support decision-making associated with their improvement, seeking to give them objective and pertinent elements that lead to the generation of an improvement plan with defined objectives, goals, strategies and programming that guide attention to the recommendations and, therefore, to the continuous improvement of the educational program (Márquez Jiménez, 2004) [11].

The methodology and frame of reference for this 2014 version were designed in a participatory manner, with the support of the different collegiate instances that participate in decision-making at CACEI, especially the Board of Directors, the area technical commissions and the academic committee. specially trained with the objective of aligning the reference framework to the requirements established in the General
Framework for the Accreditation Processes of Higher Level Academic Programs, 2012 of COPAES.

These are the ten categories that are evaluated to determine with an evaluation in Situ whether or not your program accredits

1. Academic staff.

2. Students.

3. Study plan.

4. Assessment of learning.

5. Comprehensive training.

6. Support services for learning.

7. Bonding - Extension.

8. Research or Technological Development.

9. Infrastructure and equipment.

10. Administrative management and financing

The first category of analysis is academic staff and its object of study is aimed at human resources who perform the substantive functions associated with teaching, research, extension and linkage. The second is oriented to the analysis of students from recruitment to the results associated with their school performance; the third, study plan, analyzes its characteristics, its relevance, the curricular map, the organization, the characteristics of the programs, its structure and its relationship with the educational and pedagogical model.

The fourth, learning evaluation, is oriented to the strategies used for the evaluation, while the comprehensive training analyzes the attention programs for students at risk, the cultural, sports and entrepreneurship programs, as well as the school-family relationship. Category six analyzes support services for learning includes tutoring, counseling and the job market among others; In the seventh, the mechanisms of the outreach and outreach programs and their impact on the program are reviewed.

The eighth category analyzes research, technological development, or both, carried out by academics in coordination with students of the educational program in the lines and projects associated with it. The ninth category is associated with the infrastructure from classrooms, laboratories and minimum workshops required for the program, as well as the essential equipment for them. This category includes preventive and corrective maintenance programs for the equipment, as well as safety mechanisms and procedures, and manuals, among others. The last one reviews the administrative processes associated with the program, as well as the financial and resources associated with it. (New CACEI 2014 reference framework)

Once the categories are known by the directive and administrative authorities of the educational institution, a CACEI coordinator is appointed for the educational program to be accredited, who has to give training on the ten categories to those responsible for each category, and train students about the accreditation process because they are also evaluated by CACEI evaluators (CACEI, 2020) [6].

It is also in charge of doing a self-evaluation answering the CACEI guide and with digital evidence of documents that are requested from each of the ten categories and that have to be 
uploaded to the CACEI platform.

\subsection{Non-conformity and Corrective Action}

It should be emphasized that in the ISO 9001: 2015 Standard, the role of leadership is very important to implement the desired quality system, not only with a charismatic leadership, but also decisive and innovative in search of continuous improvement [2] developed theoretical models and instruments to underpin research on transformational and charismatic leadership) [14].

The exhortation could be made to look for directive leaders of schools who have a thought of transforming the traditional into new methods that are effective, and efficient and in terms of the transformational, it can be cited here alluding to the concept of the transformational leader that was identified in 1990 through characteristics such as charisma, with inspiring motivation, intellectual stimulation and individual consideration, described in the broad spectrum model of leadership [2].

According to the previous paragraph, the need arises according to González, F., that the characteristic trait of managers with creative thinking have greater decision-making capacity, where the nature of creativity requires knowing how to move and what decisions to make at the appropriate time or otherwise it will be specified to follow the current of the traditional and static of the educational institution [12].

Finally in this consideration of leadership, considers that the old paradigms in the way of leading must be broken. Every leader must go further, in the simple fact of managing, for him, it is to go forward, show the way, influence and promote the talent of people to give the best of himself. This same author argues that he considers that in difficult times, with rapidly changing environments, and with a high degree of globalization, managers must reinforce their ambition to do things better than others, anticipate and be differential, for which they must put all his knowledge and all his skills at stake.

\section{Results}

Regarding accreditation, the self-evaluation for the Industrial Engineering Program at ITSLP is shown below.

Table 1. SUMMARY OF THE EVALUATION OF INDICATORS.

\begin{tabular}{|c|c|c|c|c|c|c|c|c|}
\hline \multicolumn{9}{|l|}{ RESUMEN DE LA EVALUACIÓN DE LOS INDICADORES } \\
\hline INSTITUTO TECNOLÓGICO DE SAN LUIS POTOSÍ & \multicolumn{8}{|c|}{ INGENIERÍA INDUSTRIAL } \\
\hline \multirow[t]{2}{*}{ INGENIERÍA INDUSTRIAL } & \multicolumn{8}{|c|}{ AGOSTO 2015.} \\
\hline & \multicolumn{8}{|c|}{ Requisitos Esenciales } \\
\hline \multirow[t]{3}{*}{ Indicador } & \multirow{2}{*}{\multicolumn{4}{|c|}{$\begin{array}{l}\text { Mínimos } \\
\text { (Indispensables) }\end{array}$}} & \multicolumn{4}{|c|}{ Complementarios } \\
\hline & & & & & (Nec & & & \\
\hline & $\mathbf{C N}$ & $\mathbf{P}$ & $\mathbf{M}$ & $\mathbf{A}$ & $\mathbf{C N}$ & $\mathbf{P}$ & M & $\mathbf{A}$ \\
\hline \multicolumn{9}{|l|}{ 1. PERSONAL ACADÉMICO } \\
\hline -Reclutamiento & & & & & A & & & \\
\hline -Selección & A & & & & & & & \\
\hline -Contratación & & & & & A & & & \\
\hline -Desarrollo del Personal Académico & A & & & & & & & \\
\hline -Categorización y nivel de estudios & M & & & & & & & \\
\hline -Distribución de las actividades sustantivas de los profesores de tiempo completo & & & & & M & & & \\
\hline -Evaluación & A & & & & & & & \\
\hline -Promoción & & & & & A & & & \\
\hline \multicolumn{9}{|l|}{ 2. ESTUDIANTES } \\
\hline -Selección & A & & & & & & & \\
\hline -Ingreso & & & & & A & & & \\
\hline -Trayectoria escolar & M & & & & & & & \\
\hline -Tamaño de los grupos & & & & & M & & & \\
\hline -Titulación & & & & & A & & & \\
\hline \multirow{2}{*}{\multicolumn{9}{|c|}{ 3. PLAN DE ESTUDIOS }} \\
\hline & & & & & & & & \\
\hline -Fundamentación & & & & & A & & & \\
\hline -Perfiles de ingreso y egreso & A & & & & & & & \\
\hline - Normativa para la permanencia, equivalencia, revalidación y egreso & & & & & A & & & \\
\hline $\begin{array}{l}\text {-Programas de las asignaturas (este criterio considera elementos de la estructura curricular como la } \\
\text { articulación horizontal y vertical, por lo que deberá revisarse su nombre) }\end{array}$ & A & & & & & & & \\
\hline -Contenidos & & & & & A & & & \\
\hline -Flexibilidad curricular & & & & & M & & & \\
\hline -Evaluación y actualización & M & & & & & & & \\
\hline -Difusión & & & & & M & & & \\
\hline \multicolumn{9}{|l|}{ 4. EVALUACIÓN DEL APRENDIZAJE } \\
\hline -Metodología & M & & & & & & & \\
\hline -Becas, reconocimientos y estímulos & & & & & M & & & \\
\hline \multicolumn{9}{|l|}{ 5. FORMACIÓN INTEGRAL } \\
\hline -Desarrollo del emprendimiento & M & & & & & & & \\
\hline -Actividades culturales & M & & & & & & & \\
\hline
\end{tabular}




\begin{tabular}{|c|c|c|c|c|c|c|c|c|}
\hline \multicolumn{9}{|l|}{ RESUMEN DE LA EVALUACIÓN DE LOS INDICADORES } \\
\hline INSTITUTO TECNOLÓGICO DE SAN LUIS POTOSÍ & \multicolumn{8}{|c|}{ INGENIERÍA INDUSTRIAL } \\
\hline \multirow[t]{2}{*}{ INGENIERÍA INDUSTRIAL } & \multicolumn{8}{|c|}{ AGOSTO 2015.} \\
\hline & \multicolumn{8}{|c|}{ Requisitos Esenciales } \\
\hline \multirow[t]{3}{*}{ Indicador } & \multicolumn{4}{|c|}{ Mínimos } & \multicolumn{4}{|c|}{ Complementarios } \\
\hline & \multicolumn{4}{|c|}{ (Indispensables) } & \multicolumn{4}{|c|}{ (Necesarios) } \\
\hline & $\mathbf{C N}$ & $\mathbf{P}$ & $\mathbf{M}$ & $\mathbf{A}$ & $\mathbf{C N}$ & $\mathbf{P}$ & M & $\mathbf{A}$ \\
\hline -Actividades deportivas & $\mathrm{M}$ & & & & & & & \\
\hline - Orientación profesional y eventos científicos o tecnológicos & & & & & M & & & \\
\hline - Orientación para prevención de actitudes de riesgo & M & & & & & & & \\
\hline -Servicios medicos & & & & & M & & & \\
\hline -Vinculación escuela - familia & & & & & M & & & \\
\hline \multicolumn{9}{|l|}{ 6. SERVICIOS DE APOYO AL APRENDIZAJE } \\
\hline Programa Institucional de tutorías & $\mathrm{M}$ & & & & & & & \\
\hline -Asesorías académicas & & & & & M & & & \\
\hline -Biblioteca & A & & & & & & & \\
\hline \multicolumn{9}{|l|}{ 7. VINCULACIÓN - EXTENSIÓN } \\
\hline -Vinculación con los sectores público, privado y social & $\mathrm{M}$ & & & & & & & \\
\hline -Seguimiento de egresados & $\mathrm{M}$ & & & & & & & \\
\hline - Intercambio académico & & & & & M & & & \\
\hline - Servicio social & A & & & & & & & \\
\hline - Bolsa de trabajo & & & & & M & & & \\
\hline -Extensión & & & & & M & & & \\
\hline \multicolumn{9}{|l|}{ 8. INVESTIGACIÓN O DESARROLLO TECNOLÓGICO } \\
\hline - Líneas y proyectos de investigación & M & & & & & & & \\
\hline - Recursos para la investigación & & & & & M & & & \\
\hline - Difusión de la investigación & & & & & $\mathrm{P}$ & & & \\
\hline - Impacto de la investigación & & & & & $\mathrm{P}$ & & & \\
\hline \multicolumn{9}{|l|}{ 9. INFRAESTRUCTURA Y EQUIPAMIENTO } \\
\hline - Infraestructura & A & & & & & & & \\
\hline - Tecnologías de la Información y Comunicación & A & & & & & & & \\
\hline \multicolumn{9}{|l|}{ 10. GESTIÓN ADMINISTRATIVA Y FINANCIAMIENTO } \\
\hline - Planeación, organización y evaluación & M & & & & & & & \\
\hline - Administración de servicios de apoyo & & & & & M & & & \\
\hline - Recursos financieros & & & & & M & & & \\
\hline \multicolumn{9}{|l|}{ Requisitos: } \\
\hline $\mathrm{CN}$ - casi nada & M - 1 & ian & & & & & & \\
\hline $\mathrm{P}$ - poco & $A-a$ & iam & & & & & & \\
\hline
\end{tabular}

In this case, the result of the accreditation of the study program was positive

For other institutions in the negative case, the bases will already be available to return to compete with more certainty because it will be known in which categories evidence is required.

Regarding certification, it is currently ISO 9001: 2008 certified, but a course on the ISO 9001: 2015 Standard was given to teachers who want to be internal auditors of the Quality Management System, a knowledge test was presented on the Standard and individual certificates as internal auditors will be awarded.

And with this team of internal auditors it is expected that the institution can continue to strengthen the Quality System in future years, and continue to train teachers because continuous improvement never ends.

\section{Conclusions}

Based on the CACEI accreditation programs and the effort made by educational institutions to improve, there are currently 932 accredited Institutions, of which there are 466 Technological, (December 2015, according to data from CACEI).
According to data from the University Academic Observatory, Space for Monitoring and Analysis of Institutional Life of the UABC and Higher Education in General, there are 11,632 higher education institutions, 2016.

Which gives us an idea that there is still a long way to go in terms of a higher quality education in Mexico.

The ITSLP of San Luis Potosí has accredited its Industrial Engineering Program since 2005 and the accreditation for 2016 is currently in process, it is not difficult, but it is not easy either as it requires a synergy of all the departments of the institution that support the transformation of students into Industrial Engineers.

It has also been ISO 9001 certified to date and work is already underway on the implementation of ISO 9001: 2015.

And what do you think, kind reader of this article?

They are encouraged to implement quality programs that lead their Higher Education Educational Institution to better levels of educational quality [8] through their role as engineers in the different branches that as graduates contribute their knowledge to continue raising educational quality in their different countries and with their own Standards that they have to adopt and adapt to their context.

If others are achieving it, why not do it ourselves? [15] 


\section{Appendix}

Guide to complying with CACEI categories to comply with accreditation and certification

These Are the Points of the ISO 9001: 2015 Standard

General Introduction for Certification

The adoption of a quality management system is a strategic decision for an organization that can help it improve its overall performance and provide a solid foundation for sustainable development initiatives.

Principles of quality management

The principles of quality management are:

- customer focus;

- leadership;

- people's commitment;

- process approach;

- improvement;

- evidence-based decision making;

- Relationship management

Process approach General

- This International Standard promotes the adoption of a process approach when developing, implementing and improving the effectiveness of a quality management system, in order to increase customer satisfaction by meeting customer requirements.

- Relationship with other management system standards

This International Standard applies the reference framework developed by ISO to improve alignment between its International Standards for management systems.

This International Standard allows an organization to use the process approach, in conjunction with the PDCA cycle and risk-based thinking, to align or integrate its quality management system with the requirements of other management system standards.

This International Standard is related to ISO 9000 and ISO 9004 as follows:

- ISO 9000 Quality management systems. Fundamentals and vocabulary, provides an essential reference for the proper understanding and implementation of this International Standard.

- ISO 9004 Management for the sustained success of an organization... Quality management approach, provides guidance for organizations that choose to go beyond the requirements of this International Standard.

Context of the organization

Understanding the organization and its context

The organization shall determine the external and internal issues that are relevant to its purpose and strategic direction, and that affect its ability to achieve the intended results of its quality management system.

-Understanding the needs and expectations of stakeholders

-Due to its effect or potential effect on the organization's ability to regularly provide products and services that satisfy customer and applicable legal and regulatory requirements, the organization must determine:

a) interested parties that are relevant to the quality management system;

-Determination of the scope of the quality management system

The organization must determine the limits and applicability of the quality management system to establish its scope.

-Quality management system and its processes

-The organization shall establish, implement, maintain and continuously improve a quality management system, including the necessary processes and their interactions, in accordance with the requirements of this International Standard.

The organization shall determine the processes necessary for the quality management system and its application throughout the organization, and shall:

a) determine the required inputs and the expected outputs from these processes;

To the extent necessary, the organization shall:

a) maintain documented information to support the operation of its processes;

b) retain documented information to have confidence that processes are performed as planned.

Leadership (Antonakis \& House, 2002)

-Leadership and commitment

-General

Top management must demonstrate leadership and commitment to the quality management system:

-Customer focus

Top management must demonstrate leadership and commitment to customer focus by ensuring that:

a) Customer and applicable legal and regulatory requirements are determined, understood and regularly met; 
Policy

-Establishment of the quality policy

Top management must establish, implement and maintain a quality policy that:

a).- is appropriate to the purpose and context of the organization and b).-Communication of the quality policy

c).-Roles, responsibilities and authorities in the organization

Top management should ensure that the responsibilities and authorities for the relevant roles are assigned, communicated and understood throughout the organization.

It is important before moving on to point 6 of the standard, to underpin the transformational leadership that directors of educational institutions must exercise to successfully implement an ISO 9001: 2015 System, as conceptualized by Bass and Riggio (2006), the degree to which leaders are truly transformational is measured by the effect they have on their followers (Bass \& Avolio, 1990).

Planning - Actions to address risks and opportunities

-When planning the quality management system, the organization shall consider the issues referred to.

The organization shall plan:

a) actions to address these risks and opportunities;

b) Quality objectives and planning to achieve them

c) The organization shall establish quality objectives for the relevant functions and levels and the processes necessary for the quality management system.

When planning how to achieve its quality objectives, the organization must determine:

* What are you going to do;

* What resources will be required;

* Who will be responsible;

* When it will end;

* How the results will be evaluated.

Support

-Resources

- General organization

The organization shall determine and provide the necessary resources for the establishment, implementation, maintenance and continuous improvement of the quality management system.

-People

The organization must determine and provide the necessary people for the effective implementation of its quality management system and for the operation and control of its processes.

Infrastructure

The organization must determine, provide and maintain the infrastructure necessary for the operation of its processes and achieve conformity of products and services.

-Environment for the operation of the processes

The organization must determine, provide and maintain the environment necessary for the operation of its processes and to achieve conformity of products and services.

-Monitoring and measurement resources

-General resources

The organization shall determine and provide the necessary resources to ensure the validity and reliability of the results when monitoring or measuring to verify the conformity of products and services with requirements.

-Knowledge of the organization

The organization must determine the knowledge necessary for the operation of its processes and to achieve conformity of products and services.

Documented information

General documentation

The organization's quality management system must include:

a.- the documented information required by this International Standard;

-Control of documented information

-The documented information required by the quality management system and by this International Standard shall be controlled to ensure that:

a) is available and suitable for use, where and when it is needed;

-For the control of documented information, the organization shall address the following activities, as appropriate:

-Competition

The organization must:

a) determine the necessary competence of the people who perform, under their control, work that affects the performance and effectiveness of the quality management system; 


\section{- Awareness}

The organization shall ensure that persons performing work under the organization's control are aware of:

a) the quality policy;

- Communication

The organization shall determine the internal and external communications relevant to the quality management system, including:

Operation

-Operational planning and control

The organization must plan, implement and control the processes

-Requirements for products and services

-Communication with the customer

-Determination of requirements for products and services

-Review of requirements for products and services

-The organization shall ensure that it has the ability to meet the requirements for the products and services to be offered to customers. The organization must conduct a review before committing to supply products and services to a customer, to include:

-The organization shall retain documented information, where applicable:

a) on the results of the review;

-Changes in requirements for products and services

The organization shall ensure that, when the requirements for products and services are changed, the relevant documented information is modified, and that the relevant persons are aware of the modified requirements.

-Design and development of products and services

-General

The organization shall establish, implement and maintain a design and development process that is adequate to ensure the subsequent provision of products and services.

Design and development planning

-Inputs for design and development

The organization must determine the essential requirements for the specific types of products and services to be designed and developed. The organization should consider:

-Design and development controls

The organization shall apply controls to the design and development process to ensure that:

-Design and development outputs

The organization shall ensure that design and development outputs:

-Design and development changes

The organization shall identify, review and control changes made during the design and development of products and services, or subsequently to the extent necessary to ensure that there is no adverse impact on compliance with the requirements.

Control of externally supplied processes, products and services

-General Control

-Type and scope of control

-Information for external providers

-Production and service provision

-Control of production and service provision

The organization must implement the production and provision of the service under controlled conditions

-Identification and traceability

The organization shall use appropriate means to identify outputs, when necessary, to ensure conformity of products and services.

-Property belonging to customers or external suppliers

Preservation

The organization shall preserve outputs during production and service provision, to the extent necessary to ensure conformance to requirements.

-Post-delivery activities

The organization must meet the requirements for post-delivery activities associated with the products and services.

-Control of changes

The organization shall review and control changes to production or service provision, to the extent necessary to ensure continued compliance with requirements.

-Release of products and services

The organization shall implement the planned arrangements, at the appropriate stages, to verify that the requirements of the products and services are met. 
-Control of non-conforming outputs

-The organization shall ensure that outputs not conforming to its requirements are identified and controlled to prevent their unintended use or delivery.

-The organization shall retain documented information that: describes the nonconformity;

Performance evaluation -Monitoring, measurement, analysis and evaluation

-General evaluation

The organization must determine:

a) what needs monitoring and measurement;

Customer Satisfaction

The organization must monitor customer perceptions of the degree to which their needs and expectations are being met. The organization shall determine the methods for obtaining, monitoring and reviewing this information.

Analysis and evaluation

The organization shall analyze and evaluate the appropriate data and information arising from monitoring and measurement. -Internal audit

-The organization shall carry out internal audits at planned intervals to provide information on whether the quality management system:

-The organization must:

plan, establish, implement and maintain one or more audit programs that include the frequency, methods, responsibilities, planning requirements and reporting, which must take into account the importance of the processes involved, the changes that affect the organization and results of previous audits;

-Management review

-General management

Top management should review the organization's quality management system at planned intervals to ensure its continued suitability, adequacy, effectiveness, and alignment with the strategic direction of the organization.

-Entradas de la revisión por la dirección

-Salidas de la revisión por la dirección

Improvement

General improvement

The organization must determine and select opportunities for improvement and implement any actions necessary to meet customer requirements and increase customer satisfaction.

These should include:

a) improve products and services to meet requirements, as well as consider future needs and expectations;

b) correct, prevent or reduce unwanted effects;

c) improve the performance and effectiveness of the quality management system.

\section{References}

[1] Antonakis, J., \& House, R. (2002). The full range leadership. Transformational and charesmatic leadership, 3-33.

[2] Bass, B., \& Avolio, B. (1990). Development transformational leadership. Journal of European Industril training, 21-30.

[3] Blanco Guijarro, M. (2014). La educación de calidad para todos empieza en la primera infancia. UNESCO, 1-20.

[4] Bodarenko, N. (2007). Acerca de las definiciones de la calidad de la educación. Educere, 613-621.

[5] CACEI. (21 de 12 de 2018). http://www.cacei.org/nvfs/nvfs02/nvfs0210.php. Obtenido de.

[6] CACEI. (21 de 12 de 2020). http://cacei.org.mx/nvfs/nvfs03/nvfs0302e.php. Obtenido de.

[7] Casillas, S. (21 de 12 de 2020). https://scholar.google.com.mx/scholar?q=(Quality+and + accre ditation + in + higher + education, + Sillas + Casillas, +2015$) \&$ hl $=$ es \&as_sdt $=0$ \&as_vis $=1 \&$ oi $=$ scholart. Obtenido de.

[8] Colella, L. (2015). El discurso de la calidad educativa. UNEEN ISO 9001, 287-303.

[9] Delval, J. (2013). a escuela para el Siglo XXI. Revista electrónoca sinéctica, 1-18.

[10] Gómez, S. H. (2013). Indicadores cualitativos para la calidad de la educación. Educación y educadores, 9-24.

[11] Holaskoaga, J. (2015). Calidad de la educación superior en México. Revista de ducación superior, 85-102. Obtenido de https://www.asee.org/: $\quad$ https://www.asee.org/ https://www.definitions.net/definition/educational+program. (21 de 12 de 2020).

[12] Menchen, F. (2009). La creatividad y las nuevas tecnologías en las organizaciones modernas. La catividad, 1-20.

[13] Palacios, M. (21 de 12 de 2020). Obtenido de https://cvnet.cpd.ua.es/curriculum-breve/es/molina-palaciossergio/7356.

[14] Vívolo, C. M. (2015). Liderazgo creativo en los directores del siglo XXI. Universidad del Zulia ISSN 1315-856, 127-141.

[15] https://online.upaep.mx/campusvirtual/ebooks/diccionario.pdf. 